Dyussenova Symbat, PhD student, Lead engineer

E-mail: dusenova_s@mail.ru ORCID ID: 0000-0002-1990-3678

Abdulvaliyev Rinat, candidate tech.sci, Head of laboratory E-mail: rin-abd@mail.ru ORCID ID: 0000-0001-6747-6984

Abdykirova Gulnar, candidate tech.sci, Lead researcher E-mail: abdgul@mail.ru ORCID ID: 0000-0001-5956-4730

Kazakh National Research Technical University after K.I.Satpayev Institute of Metallurgy and Ore Beneficiation

Almaty, the Republic of Kazakhstan

\title{
THE STUDY OF THE POSSIBILITY OF OBTAINING CHROMITE CONTAINING CONCENTRATE FROM TAILINGS
}

\begin{abstract}
The article presents the possibility of additional extraction of chromite concentrate from enrichment tails of chromite containing ores by the gravitational method. The enrichment of chromitecontaining sludges by gravity methods - on a concentration table and a KNELSON centrifugal separator have been conducted. Concentration on the table for the class size sludge $-0.2+0.071 \mathrm{~mm}$ obtained chromite concentrate with $\mathrm{Cr}_{2} \mathrm{O}_{3} 48.8 \%$, a centrifugal separator KNELSON slurry on the class size -0.071 0 mm obtained in open loop chromite concentrate with $\mathrm{Cr}_{2} \mathrm{O}_{3} 42.8 \%$;
\end{abstract}

Key words: enrichment, sludge tailings, chromite, concentrate, concentration table, centrifugal separator.

Analysis of the current scientific and technical data shows the increased difficulty in innovative solutions development for metal extraction from different kinds of mineral raw materials, due to fundamental change in mineral resources base of metallurgy. Apart from polymetallic ores, complex in chemistry and intractable, the basis for the current mineral resources base is formed by technogenic production waste. In most cases, technogenic waste is not used, and their use is a threat to the environment. The most dangerous are technogenic wastes containing toxic elements, including sludge tailings of enrichment of chromite-containing ores $[1,2,3,4,12,13]$.

A fundamental disadvantage of existing technologies for processing chromite-containing ores is the formation of production waste - sludge stored in ponds - sludge collectors. Modern gravitational technologies of enrichment of chromite-containing ores make it possible to effectively obtain chromite concentrates from large and medium fractions, and fine sludge is practically not enriched due to the difficulty of separating complex minerals into chromite concentrates and waste rock.

The traditional method of enrichment of chromite ores by gravity methods consists in the stage-by-stage crushing and grinding of ore containing chromites to a particle size of $0.5 \mathrm{~mm}$ and the use of enrichment operations in heavy liquids, on depositors and (or) on concentration tables [58]. However, only large-scale chromite ore with a mass fraction of chromium oxide of $30.0 \%$ is subjected to enrichment. Get a concentrate containing 55.0\% of chromium dioxide and final tailings with a chromium dioxide content of more than $5.0 \%$. The disadvantage of this method is the low extraction of chromium dioxide in the concentrate, due to the large losses it with tailings - sludge in the form of fine particles and intergrowths. Gravity concentrates can be finished by flotation [9] and magnetic separation [10-11].

Additional extraction of chromium from these technogenic formations, taking into account the existing demand for chromium concentrates, is an important practical task.

Technical science chromium enrichment
Materials of International Practical Internet Conference "Challenges of Science" 
For research was used sludge - fine fraction (class $-0.2+0 \mathrm{~mm}$ ), tailings of the processing plant of chromite-containing ores of the Republic of Kazakhstan table. 1.2.

Table 1 - Chemical analysis of tailings of the processing plant

\begin{tabular}{|l|c|l|c|}
\hline Element & Content, \% & Element & Content, \% \\
\hline $\mathrm{Cr}_{2} \mathrm{O}_{3}$ & 25.47 & $\mathrm{Cu}$ & 0.008 \\
\hline $\mathrm{Fe}_{2} \mathrm{O}_{3}$ & 9.1 & $\mathrm{~Pb}$ & 0.05 \\
\hline $\mathrm{SiO}_{2}$ & 21.53 & $\mathrm{As}$ & 0.025 \\
\hline $\mathrm{AI}_{2} \mathrm{O}_{3}$ & 1.51 & $\mathrm{Sb}$ & 0.23 \\
\hline $\mathrm{H}_{2} \mathrm{O}$ (связанная) & 7.8 & $\mathrm{~K}$ & 0.05 \\
\hline $\mathrm{CaO}$ & 0.75 & $\mathrm{Na}$ & 0.05 \\
\hline $\mathrm{MgO}$ & 29.4 & $\mathrm{P}$ & 0.008 \\
\hline $\mathrm{MnO}_{2}$ & 0.053 & $\mathrm{C}$ & $<0.2$ \\
\hline $\mathrm{S}_{\text {общ }}$ & 0.1 & $\mathrm{Ag} \Gamma / \mathrm{T}$ & $<2.0$ \\
\hline $\mathrm{S}_{\text {сульф. }}$ & $<0.1$ & $\mathrm{Au} \Gamma / \mathrm{T}$ & $<0.05$ \\
\hline $\mathrm{Zn}$ & 0.1 & $\mathrm{Ni}$ & 0.28 \\
\hline $\mathrm{Co}$ & 0.02 & & \\
\hline
\end{tabular}

Table 2 - X-ray phase analysis of sludge tailings

\begin{tabular}{|l|l|l|}
\hline Phase name & Formula & The content of the phase, $\%$ \\
\hline Antigorite & $\mathrm{Mg}_{3} \mathrm{Si}_{2} \mathrm{O}_{5}(\mathrm{OH})_{4}$ & 41.8 \\
\hline Clinochrysotile & $\mathrm{Mg}_{3} \mathrm{Si}_{2} \mathrm{O}_{5}(\mathrm{OH})_{4}$ & 5.1 \\
\hline Lizardite-1M & $(\mathrm{Mg}, \mathrm{Fe})_{3} \mathrm{Si}_{2} \mathrm{O}_{5}(\mathrm{OH})_{4}$ & 12.5 \\
\hline Aluminum Ferrous magnesite & $\mathrm{MgAl}_{6} \mathrm{Fe}_{1.4} \mathrm{O}_{4}$ & 8.7 \\
\hline Chromite & $\left(\mathrm{Fe}_{0.52} \mathrm{Mg}_{0.48}\right) \mathrm{Cr}_{0.76}\left(\mathrm{Al}_{0.24}\right) \mathrm{O}_{4}$ & 15.3 \\
\hline Klinohlor & $\mathrm{Mg}_{6} \mathrm{Si}_{4} \mathrm{O}_{10}(\mathrm{OH})_{8}$ & 5.6 \\
\hline Aluminum Magnesium Silicate & $\mathrm{Ca}_{23.20} \mathrm{Mg}_{22.4}\left(\mathrm{Al}_{92} \mathrm{Si}_{100} \mathrm{O}_{384}\right)$ & 11.0 \\
\hline Quartz & $\mathrm{SiO}_{2}$ & - \\
\hline
\end{tabular}

The enrichment of medium and poor in quality of chromite-containing ores and technogenic raw materials is carried out according to the technological scheme of multi-stage extraction of a valuable component as it is discovered, which is based on gravity processes.

In this study, studies were conducted on the gravitational enrichment of sludge of a particle size of $-0.2+0.071 \mathrm{~mm}$ on a concentration table and $-0.071+0 \mathrm{~mm}$ on a KNELSON centrifugal concentrator model KS-MD3 of FLSmidth Company.

Data on the enrichment of sludge particle size $-0.2+0.071 \mathrm{~mm}$ on the concentration table are given in Table 4, and on enrichment of the class of paricle size $-0.071+0 \mathrm{~mm}$ on a centrifugal separator are given in Table 5.

With the enrichment of sludge on the concentration table in the open cycle, a chromite concentrate was obtained with a $\mathrm{Cr}_{2} \mathrm{O}_{3}$ content of $48.8 \%$, with its output of $29.42 \%$ and $\mathrm{Cr}_{2} \mathrm{O}_{3}$ extraction of $73.02 \%$ of the operation. The loss of chromium oxide with concentration section tails constitute $18.62 \%$, when the content of $\mathrm{Cr}_{2} \mathrm{O}_{3} 6.5 \%$.

In a centrifugal separator KNELSON in open loop obtained chromite concentrate centrifugal separator with a content of $\mathrm{Cr}_{2} \mathrm{O}_{3} 42.8 \%$, with $48.5 \%$ of its output and extracting $\mathrm{Cr}_{2} \mathrm{O}_{3} 66.64 \%$ of

Technical science chromium enrichment
Materials of International Practical Internet Conference "Challenges of Science" 
the operation. The loss of chromium oxide with centrifugal separator tails is $19.16 \%$, with a $\mathrm{Cr}_{2} \mathrm{O}_{3}$ content of $15.75 \%$.

Table 4 - Processing of sludge on the concentration table

\begin{tabular}{|l|c|c|c|c|c|}
\hline \multirow{2}{*}{ Name } & \multicolumn{2}{|l|}{ Output, \% } & $\begin{array}{l}\text { Content of } \\
\mathrm{Cr}_{2} \mathrm{O}_{3}, \%\end{array}$ & $\begin{array}{l}\text { Extraction of } \\
\mathrm{Cr}_{2} \mathrm{O}_{3}, \% \\
\text { from class }\end{array}$ & $\begin{array}{l}\text { Extraction of } \\
\mathrm{Cr}_{2} \mathrm{O}_{3}, \% \text { from } \\
\text { sludge }\end{array}$ \\
\hline $\begin{array}{l}\text { Concentrate } \\
\text { concentration table }\end{array}$ & 29.42 & 4.84 & 48.8 & 73.02 & 7.45 \\
\hline $\begin{array}{l}\text { Middling } \\
\text { concentration table }\end{array}$ & 14.3 & 2.35 & 11.5 & 8.36 & 0.85 \\
\hline $\begin{array}{l}\text { Tails of the } \\
\text { concentration table }\end{array}$ & 56.28 & 9.27 & 6.5 & 18.62 & 1.9 \\
\hline TOTAL & 100.0 & 16.46 & 15.64 & 100.0 & 10.2 \\
\hline
\end{tabular}

Table 5 - Sludge dressing on a KNELSON centrifugal separator

\begin{tabular}{|c|c|c|c|c|c|}
\hline \multirow[t]{2}{*}{ Name } & \multicolumn{2}{|l|}{ Output, $\%$} & \multirow{2}{*}{$\begin{array}{l}\text { Content of } \\
\mathrm{Cr}_{2} \mathrm{O}_{3}, \%\end{array}$} & \multicolumn{2}{|c|}{ Extraction of $\mathrm{Cr}_{2} \mathrm{O}_{3}, \%$} \\
\hline & from class & from sludge & & from class & from sludge \\
\hline $\begin{array}{l}\text { Main separation } \\
\text { concentrate }\end{array}$ & 48.5 & 32.1 & 42.8 & 66.64 & 55.0 \\
\hline $\begin{array}{l}\text { Control separation } \\
\text { concentrate }\end{array}$ & 13.6 & 9.02 & 32.8 & 14.2 & 11.72 \\
\hline Separation tails & 37.9 & 25.08 & 15.75 & 19.16 & 15.80 \\
\hline TOTAL & 100.0 & 66.2 & 31.14 & 100.0 & 82.52 \\
\hline
\end{tabular}

Yield of total concentrate containing 43,58\% $\mathrm{Cr}_{2} \mathrm{O}_{3}$ was $37.0 \%$ of the original sludge. Extraction of $\mathrm{Cr} 2 \mathrm{O} 3$ in concentrate was $62.45 \%$. The total loss of chromium in the tails and in the class of particle size $+0.2 \mathrm{~mm}$ will be $24.98 \%$, with its content $\sim 12.0 \%$.

The results of gravitational enrichment of sludge show the feasibility of applying the concentration table process for a particle size of $-0.2+0.071 \mathrm{~mm}$ and centrifugal separation for thin size classes $(-0.071+0 \mathrm{~mm})$.

\section{REFERENCES}

1. Mamyrbaev A.A. Toxicology of chromium and its compounds / A.A. Mamyrbayev. Aktobe, 2012, $284 \mathrm{p}$.

2. Ibraev I.I. Utilization of chrome-containing sludge / I.I. Ibraev, O.T. Ibraeva, M.M. Suyundinov. Metallurgist. 2012. №10. Pp. 28-30.

3. Bazarbaeva S.M., Ermagambetova J.S. Distribution of chromium and boron in the environmental components of Aktobe // Bulletin of Aktobe Regional State University. K. Zhubanova. 2015. №4. Aktobe.C. 32-35.

4. Kenzhaliyev, B., Berkinbayeva, A., Suleimenov, E. Development of fundamental principles of hydrometallurgical processes for the purpose of efficiency upgrading of metal extraction from low-grade stock // Metallurgical and Mining Industry, 2015.7 (12), pp. 138-143.

5. Gul Akar Sen. Application of Full Factorial Experimental Design and Response Surface Methodology for Chromite Benefication by Knelson Concentrator // Minerals 2016. Vol. 6 (1). P. 5 . 
6. Kumar, C.R.; Tripathy, S.K.; Rao, D.S. Characterisation and pre-concentration of chromite values from plant tailings using floatex density separator // J. Miner. Mater. Charact. Eng. 2009. 8. P. 367-378.

7. Tripathy, S.K.; Ramamurthy, Y.; Singh, V. Recovery of chromite values from plant tailings by gravity concentration // J. Miner. Mater. Charact. Eng. 2011. 10.P. 13-25.

8. Knelson, B.; ve Jones, R. A new generation of Knelson concentrators a totally secure system goes on line //Miner. Eng. 1993. 7. 201-207.

9. Gallios, G.P.; Deliyanni, E.A.; Pelek, E.N.; Matis, K.A. Flotation of chromite and Serpentine // Sep. Purif. Technol. 2007. 55.P. 232-237.

10. Aslan, N.; Kaya, H. Beneficiation of chromite concentration waste by multi-gravity separator and high intensity induced-roll magnetic separator // Arab. J. Sci. Eng. 2009. 34.P. 285-297.

11. Tripathy, S.K.; Banerjee, P.K.; Suresh, N. Magnetic separation studies on ferruginous chromite fine to enhance Cr:Fe ratio // Int. J. Miner. Metall. Mater. 2015. 22.P. 217-224.

12. Bagdaulet Kenzhalyevich Kenzhaliyev, Renata Ramilevna Iskhakova and Zamzagul Duisenovna Dosymbayeva. Sorption extraction of noble and non-ferrous metals from process leaching solutions, American Journal of Applied Sciences. Volume 12, Issue 11, P. 875-884. 2015. https://doi.org/10.3844/ajassp.2015.875.884

13. K. Kh. Nussupov, N. B. Beisenkhanov, I. K. Beisembetov, Bagdaulet Kenzhaliyev, B. Zh. Seitov, E. Dulatuly, D. I. Bakranova. The formation of TixNy and TaxNy-based diffusion barriers. Materialstoday: Proceedings, 2017. Volume 4, Issue 3, Part A, 2017, P. 4534-4541 https://doi.org/10.1016/j.matpr.2017.04.026 